\title{
ACTUARIAL VACANCY
}

The College of Business Administration, Georgia State University, is seeking to hire a Director of its Actuarial Science Program. The position, which resides in the Department of Risk Management \& Insurance, is available at any rank beginning in either June or September 1997. Candidates should have an earned doctorate or a master's degree and a fellowship designation from one of the leading actuarial societies. Candidates nearing fellowship will also be considered.

The program director must have a strong commitment to students, teaching, program management and development, and external relations with the professional actuarial community. Salary and rank are dependent upon qualifications and experience.

Send current resume and three references to Dr. Bruce A. Palmer, Chair, Department of Risk Management and Insurance, College of Business Administration, Georgia State University, P.O. Box 4036, Atlanta, GA 30302-4036.

Preference will be given to applications received by JANUARY 15, 1997.

\section{AN EQUAL EDUCATIONAL AND EMPLOYMENT OPPORTUNITY EMPLOYER.}

